\title{
Pleural Effusion Associated with Anicteric
}

\section{Hepatitis A Virus Infection - Unusual}

\section{Manifestation of a Common Disease: A Case}

\section{Report}

This article was published in the following Dove Press journal:

Pediatric Health, Medicine and Therapeutics

Fikaden Berhe Hadgu

Henok Temtime Alemu

Department of Pediatrics and Child Health, College of Health Sciences, Mekelle University, Tigray, Ethiopia
Correspondence: Fikaden Berhe Hadgu Department of Pediatrics and Child Health, College of Health Sciences, Mekelle University, PO Box 187I, Tigray, Ethiopia

Tel +25I-9|4-748-44I

Email fikadenb@gmail.com
Background: Hepatitis A infection is common in children and often presents with mild hepatic disease. The clinical manifestations of hepatitis A virus are usually related to liver damage but sometimes extrahepatic manifestations may occur.

Case Presentation: We present a case of four-year- and eight-month-old male child with anicteric hepatitis A infection associated with a pleural effusion. The patient presented with abdominal pain, low-grade fever, loss of appetite, and vomiting of ten days duration. On examination, there was dullness and decreased air entry on the lower third of the lung field bilaterally and hepatomegaly of $6 \mathrm{~cm}$ below the costal margin. Ultrasonography revealed mild ascites, hepatosplenomegaly, and small bilateral pleural effusion. Immunoglobulin $\mathrm{M}$ anti-hepatitis A virus serology was positive. He was managed with supportive treatment and fully recovered after a month of follow-up. This case is reported to emphasize that hepatitis A infection should be considered in the differential diagnosis of pleural effusion in a patient with acute hepatitis even in the absence of jaundice. This is the first case of anicteric hepatitis A infection complicated with pleural effusion in children

Conclusion: This report suggests that pleural effusion can be associated with anicteric hepatitis A infection and should be included in the differential diagnosis of pleural effusion. Keywords: hepatitis A, unusual manifestation, pleural effusion, ascites

\section{Background}

Hepatitis A virus (HAV) is the most common cause of acute hepatitis in children. It is one of the public health problems particularly in low-income countries. ${ }^{1}$

Worldwide, an estimated 10 million people are infected with hepatitis A virus annually. ${ }^{2}$ HAV is transmitted primarily by ingestion of contaminated food, water, or direct contact with infectious individuals. The incidence is associated with socioeconomic status and access to safe water. ${ }^{3,4}$

The clinical presentation of HAV infections is mostly related to liver damage. But it is seldom associated with atypical manifestations including anasarca, ${ }^{5}$ pleural effusion and ascites ${ }^{6,7}$ pleural effusion, ascites, and acalculous cholecystitis ${ }^{8}$ and isolated pleural effusion. $^{9-12}$

We report a child with anicteric acute hepatitis A infection with bilateral pleural effusion and ascites, who improved with supportive management. 


\section{Case Presentation}

Four-year- and eight-month-old, previously well, male child presented with abdominal pain, loss of appetite, lowgrade intermittent fever, nausea, vomiting, and progressive abdominal distension of ten days duration. He has also cough of five days duration. There was no history of yellowish discoloration of eye or skin, bleeding or previous history of jaundice, urinary complaints, and change in urine or stool color. He has no history of contact with chronic cougher or with tuberculosis-diagnosed patients.

On examination: Blood pressure $90 / 60 \mathrm{~mm}$, pulse rate $88 /$ minute, respiratory rate 20 /minute, and temperature $37^{\circ}$ C. There was decreased air entry and dullness in the lower lung field bilaterally. Distended abdomen, fluid shift was positive; the liver was palpable $6 \mathrm{~cm}$ below the right costal margin, total liver span $11 \mathrm{~cm}$, and tender. There was some palmar pallor, otherwise normal.

On investigations, hepatitis A antibody immunoglobulin $\mathrm{M}$ was reactive, with a titer of $>10.11$. Other viral markers (hepatitis $\mathrm{B}$, hepatitis $\mathrm{C}$, and human immunodeficiency virus test was negative). Echocardiography study was normal. Other investigations are listed in Table 1.

Ultrasonography examination revealed minimal ascites, hepatosplenomegaly, and small bilateral pleural effusion. Ultrasound guided-pleural tap revealed no cells, lactic acid dehydrogenase $15 \mathrm{IU} / \mathrm{L}$, gene Xpert for tuberculosis was negative and bacteriologic culture was negative. Gastric aspirate was also done for gene Xpert and found to be negative.

Based on those investigations, the diagnosis of anicteric acute viral hepatitis A with unusual manifestations of pleural effusion and ascites was made. He was managed with supportive treatment (hydration, rest, antiemetics, a well-balanced diet). The liver enzymes were corrected within two weeks, ascites and pleural effusion disappeared after two weeks. Liver and spleen sizes were normalized after one month of follow-up.

\section{Discussion}

Hepatitis A infection in children may present in apparent, subclinical (there is evidence of liver damage on laboratory examination), symptomatic but without evidence of jaundice or with jaundice. ${ }^{10}$ Abdominal pain, fever, nausea, vomiting, fatigue, loss of appetite, abdominal distension and jaundice are common manifestations of hepatitis A virus infection in the symptomatic child. Children below 6 years are at less risk of symptomatic HAV infection and less than $10 \%$ of them manifesting with jaundice. ${ }^{1}$
Infection with hepatitis A is associated with increased morbidity, and rarely mortality. Disease severity is dependent on age. It is mostly asymptomatic in children. Full recovery occurs in $85 \%$ of the patients within three months. Mortality increases as the age increase. ${ }^{13}$

Hepatitis A infection-related pleural effusion is a rare extrahepatic manifestation in children. ${ }^{14}$ Hepatitis A infection associated with pleural effusion was reported usually on the right side of the lung. ${ }^{9,11,12}$ But bilateral effusion has also been documented. ${ }^{6,7,15}$ The exact mechanism of pleural effusion in hepatitis A infection is not well known but the following mechanisms have been postulated. Transport of fluid from diaphragmatic lymphatics or leakage from a diaphragmatic defect to the pleural cavity from coexistent ascites. ${ }^{6}$ The second postulated mechanism is a virus-induced infection of the liver, with unknown mechanisms results in effusion. ${ }^{12}$ Pleural effusion may also result from immune complex deposition, ${ }^{1}$ or direct effect of viral on pleura. ${ }^{16}$ Ascites result from venous and lymphatic obstruction. ${ }^{6}$ Pleural effusion secondary to hepatitis A resolves spontaneously even though liver damage progresses. ${ }^{12}$ Although the mechanism of pleural effusion in hepatitis A infection patient is speculated by the above mechanisms, there may not be different mechanisms for anicteric hepatitis A infection associated with pleural effusion.

Tuberculosis was ruled out for the fact that the patient had no history of contact with tuberculosis diagnosed patient or chronic cougher and negative laboratory results. Therefore, the diagnosis of anicteric acute viral hepatitis A infection with associated pleural effusion and ascites was made.

Documented case reports of HAV infection with pleural effusions showed that the presence of effusion with HAV infection did not signify poor outcome and it resolves with supportive treatment alone. ${ }^{6,8,10,11,14,17-19}$

Though the patient had nearly normal serum bilirubin $(1.5 \mathrm{mg} / \mathrm{dl})$ and the liver enzymes were highly elevated especially the alkaline phosphatase which was $1000 \mathrm{mg} /$ $\mathrm{dl}$, but since it is nonspecific to the liver it may not be exclusively signal of liver damage and also the reference range for his age is 93-309 that means 3 to 5 times elevated. However, the other enzymes specific to the liver like alanine amino transaminase were also highly elevated. The good thing was the synthetic function of the liver was not affected and that why he recovered fully.

All previously reported cases had elevated bilirubin while this child did not, so this is the first case report of 
Table I Investigations of the Patient at Presentation and During Follow-Up

\begin{tabular}{|c|c|c|c|}
\hline Investigations & At First Visit & Normal Values for His Age Range & Follow-Up (After 2 Weeks) \\
\hline Hemoglobin (gm/dl) & 10 & $11.5-14.5$ & 10.5 \\
\hline White blood cell count (cells $/ \mathrm{mm}^{3}$ ) & $13.9 \times 10^{3}$ & $4.0-12.0 \times 10^{3}$ & $12.6 \times 10^{3}$ \\
\hline \multirow[t]{2}{*}{ Differential cell count } & Neutrophils $46.5 \%$ & $54-62 \%$ & \\
\hline & Lymphocytes $42.8 \%$, & $25-33 \%$ & \\
\hline Platelet count (cells $/ \mathrm{mm}^{3}$ ) & $158 \times 10^{3}$ & $150-400 \times 10^{3}$ & $160 \times 10^{3}$ \\
\hline Peripheral smear & Normocytic normochromic & & \\
\hline Urinalysis & Non revealing & & Negative \\
\hline Bilirubin $(\mathrm{mg} / \mathrm{dl})$ total & 1.5 & $0.3-1.0$ & \\
\hline Direct & 0.5 & & \\
\hline Serum albumin $(\mathrm{mg} / \mathrm{dl})$ & 3.8 & $3.5-5.6$ & \\
\hline Aspartate transaminase $(\mathrm{U} / \mathrm{L})$ & 911 & $15-50$ & 46 \\
\hline Alanine amino transaminase (U/L) & 800 & $5-45$ & 34 \\
\hline Alkaline phosphatase $(\mathrm{U} / \mathrm{L})$ & 1000 & $93-309$ & 80 \\
\hline Serum creatinine $(\mathrm{mg} / \mathrm{dl})$ & 0.4 & $0.03-0.59$ & \\
\hline Prothrombin time (second) & 12 seconds & $10.6-11.4$ & \\
\hline International normalized ratio & 1.5 & $1-3$ & \\
\hline Erythrocyte sedimentation rate & 32 millimeters/hour & $3-13$ & 20 millimeters/hour \\
\hline
\end{tabular}

anicteric hepatitis A infection complicated with pleural effusion in children. Therefore, a patient with symptoms of acute hepatic damage and pleural effusion even without jaundice hepatitis A infection has to be considered but in developing countries like Ethiopia tuberculosis and other bacterial causes must be ruled out.

\section{Conclusions}

Pleural effusion has not been reported previously to be associated with anicteric hepatitis A viral infection. We would like to stress that although pleural effusion is rarely seen during anicteric hepatitis A, hepatitis A infection should be considered in the differential diagnosis in patients with pleural effusions, especially in developing countries. Pleural effusion is a benign and early extrahepatic complication of anicteric acute hepatitis $\mathrm{A}$ infection that resolves spontaneously.

\section{Data Sharing Statement}

All data generated or analyzed during this study are included in this case report.

\section{Ethics Approval and Consent to Participate}

Expedited approval was obtained from Mekelle University College of Health Sciences, Health Research Ethics Review Committee (HRERC) on 10/12/2018, (ERC 1531/2018).
The patient's father has provided written informed consent, confirming that the father has agreed on the case to get published.

\section{Acknowledgments}

To the patient's father for giving us consent for the publication and Ayder Comprehensive Specialized Hospital, Mekelle University, Ethiopia for ethical approval.

We are very much thankful to Dr. Hagos Gidey, who helped us in proofreading and editing the manuscript.

\section{Funding}

No fund was received. The case was observed at the home institution.

\section{Disclosure}

The authors declare that they have no competing interests.

\section{References}

1. Christenson JC, Manaloor JJ. Hepatitis A, B, and C. Pediatr Rev. 2016;37(10):426-438. doi:10.1542/pir.2015-0075

2. Wasley A, Fiore A, Bell BP. Hepatitis A in the era of vaccination. Epidemiol Rev. 2006;28:101-111. doi:10.1093/epirev/mxj012

3. Jacobsen KH, Koopman JS. The effects of socioeconomic development on worldwide hepatitis A virus seroprevalence patterns. Int J Epidemiol. 2005;34(3):600-609. doi:10.1093/ije/dyi062

4. Jacobsen KH, Koopman JS. Declining hepatitis A seroprevalence: a global review and analysis. Epidemiol Infect. 2004;132 (6):1005-1022. doi:10.1017/S0950268804002857 
5. Saha S, Sengupta M. Anasarca - an atypical presentation of hepatitis A. East J Med. 2012;17:133-134.

6. Gurka F. Ascites and pleural effusion accompanying hepatitis A infection in a child. Clin Microbiol Infect. 2000;6(5):286-287. doi:10.1046/j.1469-0691.2000.00077-3.x

7. Patel KR, Patil MG. Pleural effusion and ascites: rare complications of hepatitis A infection. Indian J Appl Res. 2018;8(1).

8. Erdem E, Urgancı N, Ceylan Y, Kara N, Ozcelik G, Gulec SG. Hepatitis A with pleural effusion, ascites and acalculous cholecystitis. Iran J Pediatr. 2010;20(4):479-482.

9. Bukulmez A, Koken R, Melek H, Dogru O, Ovali F. Pleural effusion: a rare complication of hepatitis A. Indian J Med Microbiol. 2008;26 (1):87-88. doi:10.4103/0255-0857.38871

10. Kumor M, Kumor V, Tomar R. Hepatitis A with pleural effusion: a rare association. AnnTropPaediatr. 2009;29(4):317-319.

11. Alhan E, Yıldızdaş D, Yapıcıoğlu H, Necmi A. Pleural effusion associated with acute hepatitis A infection. Pediatr Infect Dis J. 1999;18(12):1111-1112. doi:10.1097/00006454-199912000-00022

12. Tesovic G, Vukelic D, Vukovic B, Benic B, Bozinovic D. Pleural effusion associated with acute hepatitis A infection. Pediatr Infect Dis J. 2000;19(6):585-586. doi:10.1097/00006454-200006000-00027
13. Ciocca M. Clinical course and consequences of hepatitis A infection. Vaccine. 2000;18(Suppl 1):S71-S74. doi:10.1016/S0264-410X(99) 00470-3

14. Vinoth PN, Anitha P, Muthamilselvan S, et al. Pleural effusion - an unusual cause. Australas Med J. 2012;5(7):369-372. doi:10.4066/ AMJ.2012.1024

15. Dhaka AK, Shakya A, Shrestha D, Shah SC, Shakya H. An unusual association of pleural effusion with acute viral hepatitis A infection. Pediatric Health Med Ther. 2014;23(5):149-153. doi:10.2147/ PHMT.S70869

16. Kurt AN, Bulut Y, Turgut M, et al. Pleural effusion associated with hepatitis A. J Pediatr Inf. 2008;2:25-26.

17. Selimoğlu MA, Ziraatçi O, Tan H, Ertekin V. A rare complication of hepatitis A: pleural effusion. J Emerg Med. 2005;28(2):229-230. doi:10.1016/j.jemermed.2004.11.008

18. Prasad AN. Hepatitis A: an unusual presentation. Med $J$ Armed Forces India. 2006;62(4):389. doi:10.1016/S0377-1237(06)80120-6

19. Vaidia P, Kadam C. Hepatitis A: an unusual presentation. Indian Pediatric. 2003;40(9):910-911.

\section{Publish your work in this journal}

Pediatric Health, Medicine and Therapeutics is an international, peerreviewed, open access journal publishing original research, reports, editorials, reviews and commentaries. All aspects of health maintenance, preventative measures and disease treatment interventions are addressed within the journal. Practitioners from all disciplines are invited to submit their work as well as healthcare researchers and patient support groups. The manuscript management system is completely online and includes a very quick and fair peer-review system. Visit http://www.dovepress.com/testimonials.php to read real quotes from published authors. 